\title{
SIFAT TRANSPARANSI DAN PERMEABILITAS FILM BIONANOKOMPOSIT POLYLACTIC ACID DAN POLYCAPROLACTONE DENGAN PENAMBAHAN NANOCRYSTALLINE CELLULOSE SEBAGAI PENGISI
}

\section{[Transparency and Permeability Properties of Bionanocomposite Film of Polylactic Acid and Polycaprolactone, with Addition of Nanocrystalline Cellulose as a Filler]}

\author{
Eti Indarti*1, Arisa Sri Marlita ${ }^{1}{\text { dan } \text { Zaidiyah }^{1}}^{1}$ \\ ${ }^{1}$ Jurusan Teknologi Hasil Pertanian, \\ Fakultas Pertanian, Universitas Syiah Kuala \\ *Email korespondensi: eti_indarti@unsyiah.ac.id \\ Diterima: 22 April 2020 \\ Disetujui : 15 Agustus 2020 \\ DOI: http://dx.doi.org/10.23960/jtihp.v25i2.81-89
}

\begin{abstract}
Production of Polylactic acid (PLA)/Polycaprolactone (PCL) bionanocomposite films with various ratios was done by adding nanocrystalline celullose (NCC) from oil palm empty fruit bunches (OPEFB) as a filler. The aim of the research was to find out the effect of PLA/PCL ratio on film thickness, transparency of bionanocomposite films and water vapor permeability or WVP of the film bionanocomposite with addition of the $3 \%$ NCC. The PLA/PCL ratio are $1.0 / 0.0 ; 0.8 / 0.2 ; 0.6 / 0.4 ; 0.5 / 0.5 ; 0.4 / 0.6 ; 0.2 / 0.8$; and 0.0/1.0, prepared with solvent casting method. Characterization of PLA/PCL bionanocomposites film performed was thickness, transparency test and water vapor permeability (WVP) test. The thickness of bionanocomposites film produced were around are about 0.036-0.053 mm, results show that the lower PLA/PCL ratio the thicker film obtained. The highest value of film transparency was obtained at a ratio of $1.0 / 0.0(81.4 \%$ at a wavelength of $550 \mathrm{~nm}$ ), the smaller the PLA / PCL ratio, the lower the value of transparency. The WVP value of PLA/PCL bionanocomposite films gives a lower value than the WVP value of pure PLA film and pure PCL film. The best WVP was obtained at a PLA/PCL ratio of $0.8 / 0.2$ which was $1.49 \times 10-16 \mathrm{~kg} . \mathrm{m} /(\mathrm{m} 2 . \mathrm{s} . \mathrm{Pa})$.
\end{abstract}

Keywords: bionanocomposite, polylactic acid, polycaprolactone, nanocrystalline cellulose

\begin{abstract}
ABSTRAK
Pembuatan film bionanokomposit Polylactic acid (PLA)/Polycaprolactone(PCL) dengan berbagai rasio dilakukan dengan menambah nanocrystalline celullose $(\mathrm{NCC})$ dari tandan kosong kelapa sawit (TKKS) sebagai pengisi. Tujuan dari penelitian ini untuk melihat pengaruh rasio PLA dan PCL terhadap ketebalan, transparasi film bionanokomposit dan permeabilitas terhadap uap, dengan penambahan NCC 3\%. Rasio PLA/PCL adalah $1,0 / 0,0 ; 0,8 / 0,2 ; 0,6 / 0,4 ; 0,5 / 0,5 ; 0,4 / 0,6 ; 0,2 / 0,8 ; 0,0 / 1,0$ dipersiapkan dengan metode pencetakan larutan. Karakterisasi film bionanokomposit PLA/PCL yang dilakukan adalah, ketebalan, uji transparansi dan permeabilitas uap air atau water vapor permeability (WVP). Ketebalan film bionanokomposit yang dihasilkan berkisar 0,036-0,053 mm, semakin kecil rasio PLA/PCL semakin tebal film yang dihasilkan. Nilai transparasi film tertinggi diperoleh pada rasio 1:0 (81,4\% pada panjang gelombang $550 \mathrm{~nm})$, semakin kecil rasio PLA/PCL maka semakin rendah nilai transparasi. Nilai permeabilitas uap air atau water vapor permeability (WVP) film bionanokomposit PLA/PCL memberikan nilai lebih rendah dari pada nilai WVP film PLA murni dan PCL murni. WVP terbaik diperoleh pada rasio PLA/PCL 0,8/0,2 yaitu $1,49 \times 10^{-16} \mathrm{~kg} \cdot \mathrm{m} /\left(\mathrm{m}^{2}\right.$.s.Pa).
\end{abstract}

Kata kunci : bionanokomposit, polylactic acid, polycaprolactone, nanocrystalline cellulose 


\section{PENDAHULUAN}

Penggunaan kemasan plastik berbahan baku minyak bumi menjadi perhatian utama karena menimbulkan dampak negatif terhadap lingkungan. Produksi biopolimer alami menjadi penting sebagai antisipasi mengurangi kerusakan lingkungan, salah satu bioplastik yang memiliki sifat mendekati plastik sintetis adalah Polylactic Acid (PLA). PLA merupakan biopolimer yang bersifat renewable dan biodegradable. PLA diproduksi menggunakan bahan baku pati jagung melalui proses addisi polimer dari monomer asam laktat (Lasprilla et al., 2012; Vatansever et al., 2019). Polimer PLA memiliki sifat yang kuat, transparan, dan tahan air. Kelemahannya yaitu kaku dan memiliki sifat permeabilitas yang rendah (Fortunati et al., 2012). Untuk mengatasi permasalahan tersebut beberapa penelitian untuk memperbaiki sifat biokomposit PLA telah dilakukan, yaitu dengan menambahkan material serat sebagai penguat untuk memperbaiki karakter polimer PLA, seperti selulosa nanowhiskers dari bambu (Qian and Sheng, 2017), serat dari kulit durian (Manshor et al., 2014), serat rami (Baheti et al., 2013), Penambahan material serat memperbaiki sifat PLA murni selain bahan selulosa, beberapa polimer lainnya juga telah ditambahkan ke dalam PLA dengan tujuan mengurangi kekurangan serta perbaikan karakter biokomposit tersebut. Hamad et al. (2012) mencampurkan PLA dengan Low density polyethylene (LDPE) dan menemukan bahwa sifat mekanik campuran PLA dan LDPE semakin baik dengan semakin tingginya konsentrasi PLA. Peneliti lain juga telah melaporkan bahwa campuran PLA dan Polyhydroxybutyrate (PHB) dengan penambahan 5\% chitosan dan plasticizer, menghasilkan sifat termal dan mekanik yang lebih baik dan terdegradasi dengan sempurna (Arrieta et al., 2016). Polimer lainnya yang potensial untuk perbaikan karakter PLA adalah Polycaprolactone (PCL). PCL merupakan po- limer sintetik namun dapat terdegradasi dengan baik (Garcia-Garcia et al., 2018). PCL telah diteliti dengan penambahan selulosa asetat dan asam laktat untuk menghasilkan tulang penyokong (Hwang et al., 2019). Campuran PCL dan PLA juga telah diteliti dengan penambahan mikrokristalin selulosa untuk melihat laju degradasi pada temperatur termofilik (Kalita et al., 2020).

Penelitian sebelumnya oleh Indarti et al., (2016) menemukan bahwa PLA yang ditambahkan nanocrystalline cellulose (NCC) 3\% menghasilkan variasi film dengan nilai kuat tarik terbaik sebesar 33,42 MPa. NCC yang digunakan berasal dari tandan kosong kelapa sawit (TKKS) dan berfungsi sebagai penguat biokomposit PLA.

TKKS merupakan limbah sawit yang paling potensial digunakan sebagai bahan baku selulosa, karena memiliki kandungan selulosa lebih tinggi dibandingkan dengan limbah sawit lainnya yaitu 45,95\% (Moon et al., 2011). Tingginya kandungan selulosa pada TKKS dapat dimanfaatkan sebagai bahan dasar pembuatan nanocrystalline celullose (NCC). NCC merupakan material jenis baru yang dapat diisolasi dari selulosa dan memiliki ukuran nano dengan panjang mencapai 100-500 nm dan lebar 2$6 \mathrm{~nm}$ (Habibi et al., 2010). NCC dapat dimanfaatkan sebagai filler dalam pembuatan plastik biodegradable (Sessini et al., 2018).

PLA dan PCL memiliki sifat yang sama, yaitu bersifat hidrofobik dan dapat terdegradasi dengan baik. Namun, kedua polimer ini memiliki perbedaan sifat fisik, yaitu PLA bersifat sangat transparan namun memiliki karakter yang kaku dan permeabilitas yang rendah, sedangkan PCL bersifat tidak transparan memiliki sifat yang sangat fleksibel dan kuat, sehingga apabila kedua senyawa ini dipadukan maka polimer yang dihasilkan dapat memperbaiki kekurangan dari sifat yang dimiliki oleh polimer aslinya (Wachirahuttapong et al., 2016). Pada pembuatan PLA/PCL, Wachi- 
rahuttapong et al. (2016) menghasilkan bionanokomposit yang tidak saling larut dengan bertambah besarnya konsentrasi PCL, selain itu terjadi penurunan kristalinitas pada campuran PLA/PCL yang dihasilkan. Untuk mengatasi beberapa kekurangan film PLA/PCL tersebut, maka pada penelitian ini dilakukan pencampuran polymer PLA/PCL dari berbagai rasio dengan penambahan nanocrystalline cellulose (NCC) sebanyak 3\%. Penelitian ini diharapkan film yang memiliki nilai transparasi yang lebih baik dan mampu menurunkan permeabilitas uap air. Film bionanokomposi PLA/PCL yang diperoleh akan dibandingkan dengan film komersil HDPE yang memiliki ketebalan $\pm 0,04$ $\mathrm{mm}$.

\section{BAHAN DAN METODE}

\section{Bahan dan Alat}

Bahan yang digunakan adalah TKKS, katalis TEMPO, $\mathrm{NaOCl}, \mathrm{NaBr}$, $\mathrm{NaOCl}_{2}, \mathrm{CaCl}_{2}$ semua bahan kimia diperoleh dari Merck, Polylactic Acid (PLA; AI-1001 Shenzhen ESUN Industrial Co.Ltd.), Polycaprolactone (PCL; Merck cat. No. 440744), film paraffin-M (laboratory film). Alat-alat yang digunakan adalah ultrasonik (Bransonic 1510E-MT, USA), sentrifuse (Hettich Zentrifugen EBA-20), magnetic stirer, saringan 400 mesh, RH-meter (Chino, Cororation HN-K, Japan). Alat uji ketebalan Micrometer Dial Thickness Gauge G-6C (Peacock, Japan), WVP (Water Vapor Permeability) dan Uv-Vis Shimadzu UV-1700.

\section{Metode Penelitian}

\section{Persiapan Nanocrystalline Cellulose}

Selulosa nanokristal diperoleh dari serat tandan kosong kelapa sawit (TKKS) melalui proses oksidasi menggunakan katalis TEMPO. Bahan baku terlebih dahulu melewati proses pra -hidrolisa dan soda pulping mengikuti prosedur Wanrosli et al. (2004). Pulp yang dihasilkan selanjutnya direaksikan dengan $\mathrm{NaBr}$ dan $\mathrm{NaOCl}$ menggunakan katalis TEMPO mengikuti prosedur yang diterapkan oleh Indarti et al. (2015) . Pemisahaan NCC menggunakan proses sonikasi selama 30 menit dan dilanjutkan sentrifugasi dengan kecepatan $3500 \mathrm{rpm}$ selama 1 jam. Suspensi NCC selanjutnya dikeringkan dalam oven pada suhu $40^{\circ} \mathrm{C}$ hingga kering dan disaring menggunakan saringan 400 mesh.

\section{Pembuatan Bionanokomposit}

Pembuatan film bionanokomposit PLA/PCL menggunakan metode pencetakan dengan pelarut mengikuti metode Indarti et al. (2016). Rasio polimer PLA dan PCL adalah $1,0 / 0,0 ; 0,8 / 0,2 ; 0,6 / 0,4$; $0,5 / 0,5 ; 0,4 / 0,6 ; 0,2 / 0,8 ; 0,0 / 1,0$. Campuran PLA/PCL dilarutkan dalam $25 \mathrm{ml}$ kloroform, dan ditambahkan NCC sebanyak 3\% kemudian diaduk dengan kecepatan pengadukan $1000 \mathrm{rpm}$ selama 2 jam. Larutan dituang pada kaca ukuran $18 \mathrm{~cm}$ x $20 \mathrm{~cm}$ dengan ketebalan sisi kaca $0,50 \mathrm{~mm}$. Kemudian film dikeringkan pada suhu ruang selama kurang lebih 24 jam. Film dilepaskan dari cetakan dan disimpan dalam desikator sebelum dilakukan analisis.

\section{Perlakuan Penelitian}

Penelitian dilakukan dengan menggunakan 8 perlakuan, yang terdiri 7 perlakuan kombinasi PLA/PCL dan satu perlakukan kontrol (HDPE). Kombinasi perlakuan disajikan pada Tabel 1. Data hasil penelitian dianalisis menggunakan metode deskriptif dan disajikan dalam bentuk grafik dan gambar.

\section{Karakterisasi Film Bionanokomposit}

Uji Ketebalan Film Bionakomposit

Ketebalan Film diukur dengan menggunakan Micrometer Dial Thickness 
Gauge (Peacock, Japan). Nilai ketebalan merupakan nilai rata rata pengukuran pada 10 titik yang berbeda.

Tabel. 1 Perlakuan penelitian

\begin{tabular}{cccc}
\hline $\begin{array}{c}\text { Rasio Bi- } \\
\text { onanokomposit }\end{array}$ & \multicolumn{2}{c}{ Komposisi Bahan } \\
PLA : PCL & $\begin{array}{c}\text { PLA } \\
\text { (gr) }\end{array}$ & $\begin{array}{c}\text { PCL } \\
\text { (gr) }\end{array}$ & $\begin{array}{c}\text { NCC } \\
\text { (gr) }\end{array}$ \\
\hline $1,0: 0,0$ & 0,97 & 0,0 & 0,03 \\
$0,8: 0,2$ & 0,78 & 0,19 & 0,03 \\
$0,6: 0,4$ & 0,58 & 0,39 & 0,03 \\
$0,5: 0,5$ & 0,49 & 0,49 & 0,03 \\
$0,4: 0,6$ & 0,39 & 0,58 & 0,03 \\
$0,2: 0,8$ & 0,19 & 0,78 & 0,03 \\
$0,0: 1,0$ & 0,0 & 0,97 & 0,03 \\
HDPE & - & - & - \\
\hline
\end{tabular}

\section{Uji UV-Vis dan Transparasi}

Transparansi film bionanokomposit diukur dengan menggunakan UV-Vis Spektrofotometer pada panjang gelombang ( $\lambda$ ) 300-700 nm. Pengujian dilakukan dengan melewatkan cahaya hingga melewati film yang ditempel pada dinding kuvet. Cahaya yang dilewatkan diukur sebagai \% Transmitan (T).

\section{Water Vapor Permeability}

Water Vapor Permeability (WVP) adalah melihat ketahanan film bionanokomposit dalam menahan uap air. Laju transmisi uap air terhadap bionanokomposit PLA/PCL diuji dengan menggunakan metode UNE-53097 (2002). Analisis WVP dilakukan dengan meletakkan film di atas cawan kaca (diameter 4 $\mathrm{cm}$ ) dan direkatkan menggunakan paraffin film. Selanjutnya $\mathrm{CaCl}_{2}$ yang bersifat sangat higroskopis diletakkan di dalam cawan, dan selajutnya ditimbang hingga laju kenaikan berat cawan konstan.

Rumus yang digunakan untuk melihat nilai WVP disajikan dalam Rumus 1.

$$
\mathrm{WVP}=\frac{\text { WVTR }}{\mathrm{Ps}(\mathrm{RH} 1-\mathrm{RH} 2)} \mathrm{x} \delta \mathrm{m}
$$

Keterangan:

WVP = Water vapor permeability $(\mathrm{kg} \cdot \mathrm{m} /$ $\left(\mathrm{m}^{2}\right.$.s.Pa)

WVTR $=$ Laju transmisi uap air $\left(\mathrm{g} / \mathrm{m}^{2} . \mathrm{s}\right)$

$\mathrm{P}_{\mathrm{s}} \quad=$ Tekanan uap air jenuh $(\mathrm{Pa})$

$\mathrm{RH}_{1}=$ Relative humidity dalam eksikator

$\mathrm{RH}_{2} \quad=$ Relative humidity lingkungan

$\delta \mathrm{m}=$ Ketebalan rerata lapisan film (m)

\section{HASIL DAN PEMBAHASAN}

\section{Ketebalan Film Bionanokomposit}

Film bionanokomposit PLA/PCL yang dihasilkan memiliki ketebalan 0,036$0,053 \mathrm{~mm}$ (Gambar 1). Ketebalan film meningkat dengan semakin tinggi rasio PCL. Hal ini diduga karena adanya peningkatan viskositas larutan pembentuk film yang dihasilkan sebelum proses pencetakan. Yessi et al., (2013) menyebutkan bahwa ketebalan film dipengaruhi oleh konsentrasi filler dan bahan penyusunnya.

Park and Chinnan (1995) menjelaskan bahwa ketebalan film dipengaruhi oleh banyaknya total padatan dalam larutan serta luas dan volume larutan dalam cetakan yang digunakan. Namun pada penelitian ini, jumlah filler pelarut chloroform, volume dan luas cetakan adalah sama setiap perlakukan, sehingga faktor ini bukan menjadi penentu penyebab peningkatan viskositas larutan pembentuk film.

Indarti et al. (2019) menghasilkan film bionanokomposit PLA/NCC dengan berbagai konsentrasi NCC dengan ketebalan film 0,03-0,05 mm. Sedangkan, Sessini et al. (2018), melaporkan bahwa film bionanokomposit PLA/PCL dengan penambahan NCC $1 \%$ dan menggunakan proses pencetakan tekan dengan suhu $180^{\circ} \mathrm{C}$ menghasilkan film dengan ketebalan $0.5 \mathrm{~mm}$. Hal ini disebabkan film yang dihasilkan melalui proses pencetakan pelarut dapat lebih tipis dibanding dengan metode pencetakan tekan panas, karena metode pencetakan pelarut dapat diatur ketebalan dengan mengatur volume pelarut 


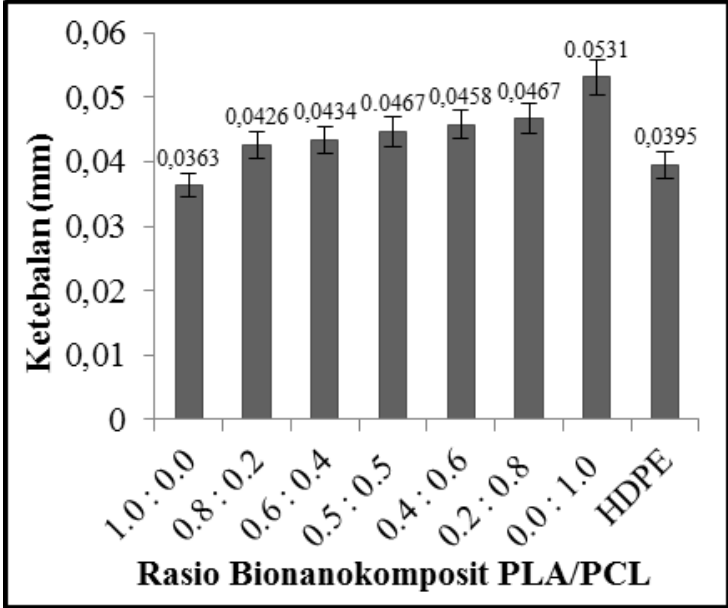

Gambar 1. Ketebalan filmbionanokomposit PLA/PCL

dan luasan cetakan sesuai dengan ketebalan yang diinginkan.

Ketebalan film bionanokomposit pada penelitian ini mendekati ketebalan plastik komersil yang digunakan untuk membungkus buah di supermarket, yaitu plastik High Density Polyethylene (HDPE) dengan ketebalan yang diperoleh 0,039 $\mathrm{mm}$.

\section{Transparansi Film Bionanokomposit}

Pengujian transparansi film menggunakan cahaya UV-Vis dilakukan untuk mengetahui nilai transmitan yang dilewatkan melalui film bionanokomposit PLA/PCL dengan penambahan NCC 3\%. Berdasarkan standar (ASTM-D1746-03, 2003), transparansi film plastik didefinisikan sebagai transmisi cahaya tampak dalam jarak pendek 540-560 nm (Ligot et al., 2015). Pengujian film bionanokomposit PLA/PCL (Gambar 2) menunjukkan nilai transmitan tertinggi diperoleh pada Film PLA/PCL dengan ratio 1:0 pada setiap panjang gelombang (300-700 nm). Semakin kecil rasio PLA/PCL menghasilkan film dengan nilai transmisi semakin rendah. $\mathrm{Pa}-$ da panjang gelombang $550 \mathrm{~nm}$, film PLA/ PCL rasio 1:0 diperoleh nilai transmitan sebesar $81.4 \%$, namun semakin kecil rasio PLA/PCL semakin menurun nilai transmitan.

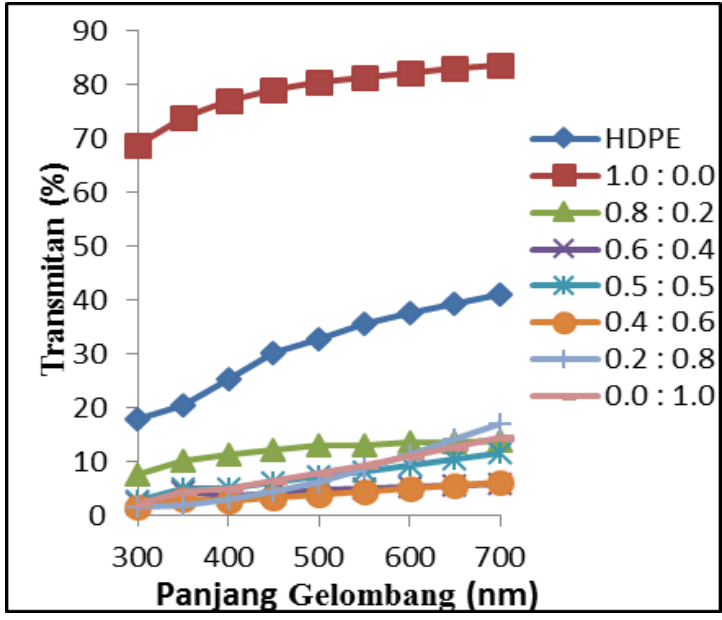

Gambar 2. Hasil Pengujian Transparansi Film Bionanokomposit PLA/PCL

Uji transparansi film juga dapat dianalisis secara visual yaitu dengan cara melihat langsung penampakan benda yang ada dibalik film tersebut. Tampilan secara visual film bionanokomposit PLA/PCL dapat dilihat pada Gambar 3. Pada Gambar 3a. film bionanokomposit PLA/PCL rasio 1:0 menampilkan gambar bunga dibalik film sangat jelas.

Semakin meningkatnya kandungan PCL atau semakin rendahnya rasio PLA/ PCL menghasilkan film yang semakin buram. Hal ini memiliki korelasi antara keburaman dan cahaya yang diteruskan pada panjang gelombang UV Vis, semakin besar panjang gelombang, maka nilai transmitan yang dihasilkan semakin besar. Nilai transmitan film bionanokomposit tidak dipengaruhi oleh ketebalan film melainkan lebih dipengaruhi oleh indeks bias bahan penyusunnya (Tang and Liu, 2008). Film bionanokomposit PLA murni memiliki transmitan lebih tinggi dari transmitan film PCL murni, meskipun film PLA murni lebih tebal dibandingkan dengan film PCL murni.

Transparansi film menjadi penting dalam produk pangan karena akan mempengaruhi bahan yang sensitive terhadap cahaya (Turhan and Şahbaz, 2001). Namun demikian, film yang transparan tetap menjadi prioritas, karena dapat melihat produk didalam kemasan lebih 
jelas dan lebih menarik. Pada penelitian ini, nilai transmisi untuk PLA/PCL pada panjang gelombang $400 \mathrm{~nm}$, dengan rasio $0,8: 0,2$ hingga rasio $0,0: 1,0$ memiliki nilai transmitan $<18.3 \%$ yang artinya mampu menyerap sinar UV hingga $80 \%$. Sehingga aplikasi yang sesuai adalah untuk kemasan bahan pangan yang sensitive terhadap sinar UV, seperti buah dan sayuran.
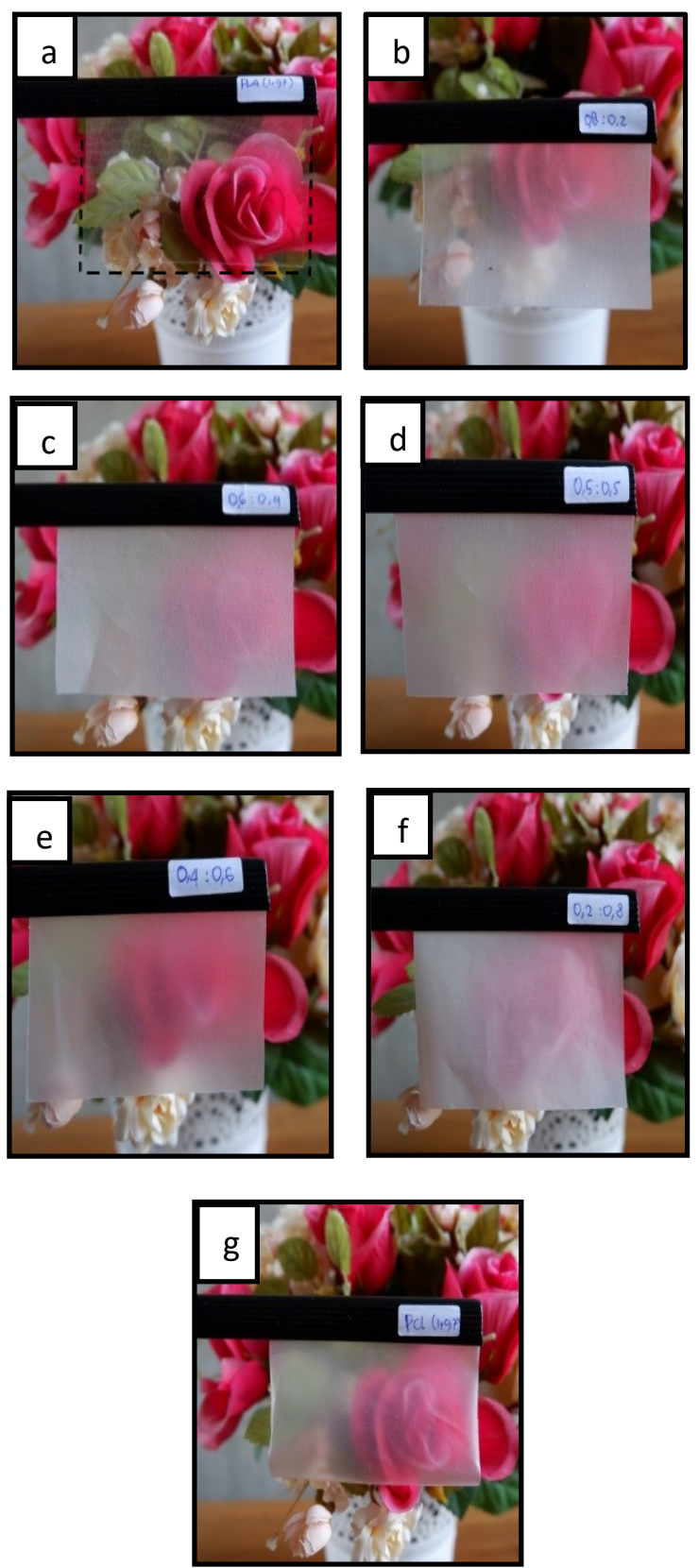

Gambar 3. FilmBionanokomposit rasio PLA/PCL (a) $1,0 / 0,0$; (b) $0,8 / 0,2 ; \quad$ (c) $0,6 / 0,4 ; \quad$ (d) $0,5 / 0,5 ;$ (e) $0,4 / 0,6 ;$ (f) $0,2 / 0,8 ;$ (g) $0,0 / 1,0$
Tabel 2. WVP film bionanokomposit PLA/ PCL dengan penambahan NCC 3\%

\begin{tabular}{ccc}
\hline $\begin{array}{c}\text { Rasio } \\
\text { PLA/PCL }\end{array}$ & $\begin{array}{c}\text { WVP x 10 } \\
(\mathrm{kg} . \mathrm{m} / \\
\left.\mathrm{m}^{2} . \mathrm{s} . P a\right)\end{array}$ & $\begin{array}{c}\text { Penurunan } \\
\text { WVP (\%) }\end{array}$ \\
\hline $1,0: 0,0$ & $1,73 \pm 0,239$ & - \\
$0,8: 0,2$ & $1,49 \pm 0,244$ & 13,873 \\
$0,6: 0,4$ & $1,57 \pm 0,021$ & 9,249 \\
$0,5: 0,5$ & $1,63 \pm 0,162$ & 5,780 \\
$0,4: 0,6$ & $1,66 \pm 0,096$ & 4,046 \\
$0,2: 0,8$ & $2,16 \pm 0,043$ & $-24,855$ \\
$0,0: 1,0$ & $2,56 \pm 0,650$ & $-47,977$ \\
HDPE & $0,37 \pm 0,063$ & - \\
\hline
\end{tabular}

\section{Water Vapor Permeability (WVP)}

Analisis WVP bertujuan untuk mengetahui kemampuan film bionanokomposit PLA/PCL menahan transmisi uap air atau disebut dengan $W$ ater $V a$ por Permeability (WVP). Semakin kecil nilai WVP indikasi bahwa semakin sedikit uap air yang dapat melewati film atau semakin baik kemampuan film menahan transmisi uap air. Pada film PLA/PCL rasio 1:0 nilai WVP sebesar $1,73 \times 10^{-16} \mathrm{~kg} . \mathrm{m} /$ $\left(\mathrm{m}^{2}\right.$.s.Pa). Nilai WVP menurun pada film PLA/PCL rasio 0.8:0.2 menjadi 1,4973 $\times 10^{-}$ ${ }^{16} \mathrm{~kg} \cdot \mathrm{m} /\left(\mathrm{m}^{2} . \mathrm{s} . \mathrm{Pa}\right)$ dan $1,49 \times 10^{-16} \mathrm{~kg} \cdot \mathrm{m} /$ $\left(\mathrm{m}^{2}\right.$.s.Pa). Sedangkan nilai WVP pada film PLA/PCL rasio $0: 1$ adalah $2,56 \times 10^{-16} \mathrm{~kg} . \mathrm{m} /$ $\left(\mathrm{m}^{2}\right.$.s.Pa). Hal ini mengindikasikan bahwa penambahan PCL pada polimer PLA menyebabkan penurunan nilai WVP dibandingkan dengan film PLA murni dan PCL murni. Nilai WVP yang lebih rendah menunjukkan bahwa ketahanan film dalam menahan transmisi uap air semakin baik. Hal ini diduga karena adanya interaksi yang baik antara polimer PLA dan PCL, selain itu PLA dan PCL bersifat hidrofobik sehingga dapat menghasilkan bionanokomposit yang memiliki struktur yang lebih kompak.

Semakin besar penambahan PCL maka terjadi peningkatan nilai WVP film, atau semakin rendah kemampuan film menahan transmisi uap air yaitu rasio PLA/ 
PCL $0,4 / 0,6 ; 0,5 / 0,5$, dan 0,6/0,4. Hal ini juga berkaitan dengan berat molekul masing-masing bahan penyusun film. Berat molekul PCL pada penelitian ini adalah $80.000 \mathrm{~g} / \mathrm{mol}$, lebih rendah dibandingkan dengan berat molekul PLA yaitu 125.000 $\mathrm{g} / \mathrm{mol}$. Penambahan 3\% NCC pada komposit PLA/PCL juga berperan dalam mengurangi nilai WVP, dimana sifat kristalin pada NCC dapat menambah alur rintangan bagi uap air melewati film. Lebih lanjut, penambahan NCC yang lebih banyak juga dapat mengikat air lebih tinggi sehingga nilai permeabilitas uap air semakin rendah (Sanchez-Garcia and Lagaron, 2010).

Fortunati et al. (2012) melaporkan bahwa dengan penambahan $\mathrm{CNC}$ (cellulose nanocrystals) sebanyak 1\% pada polimer PLA menghasilkan nilai WVP sebesar $1,05 \times 10^{-14} \mathrm{~kg} . \mathrm{m} /\left(\mathrm{m}^{2}\right.$.s.Pa $)$.

Film bionanokomposit PLA/PCL (1.0/0.0) dengan penambahan NCC 3\% menghasilkan nilai WVP yang berbeda dengan hasil penelitian yang dilakukan oleh Fortunati et al., (2012). Hal ini diduga karena adanya perbedaan berat molekul PLA yang digunakan. (Fortunati et al. (2012) menggunakan PLA dengan berat molekul $14.000 \mathrm{~g} / \mathrm{mol}$, sedangkan pada penelitian ini berat molekul PLA yang digunakan adalah $125.000 \mathrm{~g} / \mathrm{mol}$, sehingga membuktikan bahwa film yang dihasilkan pada penelitian ini lebih baik karena mampu menahan laju transmisi uap air lebih tinggi (WVP rendah).

Meskipun nilai WVP Bionanokomposit PLA/PCL pada penelitian ini $\left(1,49-2,56 \times 10^{-16}\right)$ lebih tinggi dari HDPE $\left(0,37 \times 10^{-16}\right)$, akan tetapi masih berada pada kisaran kepangkatan yang sama, yaitu $10^{-16}$. Oleh karena itu, aplikasi kemasan pada penelitian ini dianjurkan untuk kemasan buah segar.

\section{KESIMPULAN}

Ketebalan film Bionanokomposit PLA/PCL berkisar antara 0,036-0,053 mm.
Ketebalan film meningkat dengan semakin tinggi rasio PCL. Pengujian transparansi menggunakan panjang gelombang $550 \mathrm{~nm}$ menunjukkan nilai transmisi yang menurun dengan meningkatnya kandungan PCL atau rasio PLA/PCL menurun. Hal yang sama juga ditunjukkan oleh penampakan secara visual pada film bionankomposit, Film bionanokomposit PLA/PCL rasio 0,8:0,2 memiliki nilai WVP terbaik $1,4973 \times 10^{-16}$ $\mathrm{kg} . \mathrm{m} /\left(\mathrm{m}^{2} . \mathrm{s} . \mathrm{Pa}\right)$ dengan persen penurunan $13,8 \%$. Aplikasi yang danjurkan yaitu kemasan pada buah segar.

\section{DAFTAR PUSTAKA}

Arrieta, M. P., J. López, D. López, J. M. Kenny, and L. Peponi. 2016. Effect of chitosan and catechin addition on the structural, thermal, mechanical and disintegration properties of plasticized electrospun PLA-PHB biocomposites. Polym. Degrad. Stabil. 132:145-156.

ASTM-D1746-03. 2003. Standard Test Method for Transparency of Plastic Sheeting.

Baheti, V., J. Militky, and M. Marsalkova. 2013. Mechanical properties of poly lactic acid composite films reinforced with wet milled jute nanofibers. Polym. Composites. 34 (12):2133-2141.

Fortunati, E., I. Armentano, Q. Zhou, A. Iannoni, E. Saino, L. Visai, L. A. Berglund, and J. M. Kenny. 2012. Multifunctional bionanocomposite films of poly(lactic acid), cellulose nanocrystals and silver nanoparticles. Carbohyd. Polym. 87(2): 1596-1605.

Garcia-Garcia, D., J. Lopez-Martinez, R. Balart, E. Strömberg, and R. Moriana. 2018. Reinforcing capability of cellulose nanocrystals obtained from pine cones in a biodegradable poly (3-hydroxybutyrate)/poly ( $\varepsilon$ - 
capro-lactone) (PHB/PCL) thermoplastic blend. Eur. Polym. J. 104:10 -18 .

Habibi, Y., L. A. Lucia, and O. J. Rojas. 2010. Cellulose Nanocrystals: Chemistry, Self-Assembly, and Applications. Chem. Rev. 110(6): 3479-3500.

Hamad, K., M. Kaseem, and F. Deri. 2012. Poly (lactic acid)/low density polyethylene polymer blends: preparation and characterization. Asia-Pac. J. Chem. Eng. 7(S3): S310-S316.

Hwang, T. I., J. I. Kim, M. K. Joshi, C. H. Park, and C. S. Kim. 2019. Simultaneous regeneration of calcium lactate and cellulose into PCL nanofiber for biomedical application. Carbohyd. Polym. 212: 21-29.

Indarti, E., Marwan, and W. D. W. Rosli. 2019. Morphological and Optical Properties of Polylactic Acid Bionanocomposite Film Reinforced with Oil Palm Empty Fruit Bunch Nanocrystalline Cellulose. J. Phy. Conf. Ser. 1295. 012053

Indarti, E., Marwan, and W. D. Wanrosli. 2015. Thermal Stability of Oil Palm Empty Fruit Bunch (OPEFB) Nanocrystalline Cellulose: Effects of post-treatment of oven drying and solvent exchange techniques. J. Phy. Conf. Ser. 622(1):012025.

Indarti, E., R. Roslan, Marwan, and W. R. W. Daud. 2016. Polylactic Acid Bionanocomposites Filled with Nanocrystalline Cellulose from TEMPO-Oxidized Oil Palm Lignocellulosic Biomass. BioResources. 11(4):8615-8626.

Kalita, N. K., S. M. Bhasney, C. Mudenur, A. Kalamdhad, and V. Katiyar. 2020. End-of-life evaluation and biodegradation of Poly(lactic acid) (PLA)/Polycaprolactone (PCL)/ Microcrystalline cellulose (MCC) polyblends under composting con- ditions. Chemosphere. 247: 125875.

Lasprilla, A. J. R., G. A. R. Martinez, B. H. Lunelli, A. L. Jardini, and R. M. Filho. 2012. Poly-lactic acid synthesis for application in biomedical devices - A review. Biotechnol. Adv. 30(1):321-328.

Ligot, S., S. Benali, R. Ramy-Ratiarison, M. Murariu, and R. Snyders. 2015. Mechanical, optical and barrier properties of PLA-layered silicate nanocomposites coated with organic plasma polymer thin films. Mater Sci Eng Adv Res. 2015(1):1-11.

Manshor, M. R., H. Anuar, M. N. Nur Aimi, M. I. Ahmad Fitrie, W. B. Wan Nazri, S. M. Sapuan, Y. A. ElShekeil, and M. U. Wahit. 2014. Mechanical, thermal and morphological properties of durian skin fibre reinforced PLA biocomposites. Mater. Des. 59: 279-286.

Moon, R. J., A. Martini, J. Nairn, J. Simonsen, and J. Youngblood. 2011. Cellulose nanomaterials review: structure, properties and nanocomposites. Chem. Soc. Rev. 40(7):39413994.

Park, H. J. and M. S. Chinnan. 1995. Gas and water vapor barrier properties of edible films from protein and cellulosic materials. J. Food Eng. 25(4):497-507.

Qian, S. and K. Sheng. 2017. PLA toughened by bamboo cellulose nanowhiskers: Role of silane compatibilization on the PLA bionanocomposite properties. Compos. Sci. Technol. 148:59-69.

Sanchez-Garcia, M. D., and J. M. Lagaron. 2010. On the use of plant cellulose nanowhiskers to enhance the barrier properties of polylactic acid. Cellulose. 17(5):987-1004.

Sessini, V., I. Navarro-Baena, M. P. Arrieta, F. Dominici, D. López, and L. Torre. 2018. Effect of the addi- 
tion of polyester-grafted-cellulose nanocrystals on the shape memory properties of biodegradable PLA/ PCL nano composites. Polym. Degrad. Stabil. 152:126-138.

Tang, C. and H. Liu. 2008. Cellulose nanofiber reinforced poly(vinyl alcohol) composite film with high visible light transmittance. Compos. Part A-Appl. Sc. 39(10):1638-1643.

Turhan, K. N. and F. Şahbaz. 2001. A simple method for determining light transmittance of polymer films used for packaging foods. Polym. Int. 50(10):1138-1142.

UNE-53097. 2002. Sheet materialsDetermination of water vapor transmission rate - Gavimetric (dish) method.

Vatansever, E., D. Arslan, and M. Nofar. 2019. Polylactide cellulose-based nanocomposites. Int. J Biol. Macromol. 137:912-938.

Wachirahuttapong, S., C. Thongpin, and N. Sombatsompop. 2016. Effect of PCL and compatibility contents on the morphology, crystallization and mechanical properties of PLA/PCL blends. Energy Procedia. 89:198206.

Wanrosli, W. D., Z. Zainuddin, and L. K. Lee. 2004. Influence of pulping variables on the properties of Elaeis guineensis soda pulp as evaluated by response surface methodology. Wood Sci. Technol. 38(3):191-205.

Yessi, W., B. Abbas, dan N. Suryani. 2013. Pembuatan Nanokomposit Polycaprolatone-Kitosan Hidroksiapatit Iradasi Untuk Aplikasi Biomaterial. Jurnal Majalah Metalurgi, 28(2):149-160. 